\title{
Molekulákba kódolt kvantuminformáció: átmenetifém-klaszterek elektronszerkezete
}

\author{
MÁTÉ Mihály ${ }^{\mathrm{a}, \mathrm{b}}$, BARCZA Gergely ${ }^{\mathrm{a}}$, SZALAY Szilárd ${ }^{\mathrm{a}}$ és LEGEZA Örs ${ }^{\mathrm{a}}{ }^{*}$ \\ ${ }^{a}$ Erösen Korrelált Rendszerek "Lendület" kutatócsoport, MTA-Wigner Fizikai Kutatóközpont, \\ Konkoly-Thege Miklós út 29-33, 1121 Budapest \\ ${ }^{b}$ Komplex Rendszerek Fizikája Tanszék, Eötvös Loránd Tudományegyetem, \\ Pázmány Péter sétány 1/A, 1117 Budapest
}

\section{Bevezetés}

Az elektronszerkezet pontos számítása rendkívül fontos a modern kvantumkémiában és anyagtudományban. Ehhez az elektronkorreláció hatékony kezelése alapvetó és nagy kihívást jelentő feladat. Az elmúlt évtizedekben tapasztalt ugrásszerü matematikai, algoritmikus és számítástechnikai fejlődésnek köszönhetően a tenzorhálózat-algoritmusok mára olyan általános eszköztárrá nőtték ki magukat, melyekkel hatékonyan vizsgálhatók a nagy kihívást jelentő erősen korrelált molekuláris rendszerek.

Egy atom vagy molekula elektronszerkezetét leíró hullámfüggvény megfelelő közelítéséhez minden kiválasztott módszer esetén egyfajta kompromisszumot kell találnunk a megkívánt pontosság és a hozzátartozó számítási bonyolultság között. Míg az ún. gyengén korrelált elektronrendszerek vizsgálatakor a sürüségfunkcionálelmélet (DFT) [1] és a coupled cluster (CC) [2-4] módszerek napjaink vezetö algoritmusainak számítanak, nem létezik olyan univerzális módszer, mely alkalmazható lenne elektronok közötti erös korreláció esetében, mint például a nyílt héjjal rendelkező átmenetifém-klaszterek [5,6]. A párosítatlan elektronok közötti kölcsönhatás következtében az erősen korrelált rendszerek nem írhatók le egy vezető determináns gyenge perturbációjával. Mindezek tükrében tehát új módszerek kidolgozására van szükség.

$\mathrm{Az}$ erős korreláció hatásai megjelennek más tudományterületeken is, mint például szilárdtestfizikában, magfizikában és kvantumoptikában. Egy forradalmian új módszer, a sürüségmátrixos renormálásicsoport (DMRG) algoritmus [7], S. R. White munkásságának köszönhetően 1992 óta lehetővé teszi erősen korrelált spin- és elektronrendszerek hatékony számítását az alacsony dimenziós szilárdtestfizika területén [8]. Ezek olyan anyagcsaládokat írnak le, melyekben az elektronok mozgása csak kvázi egy vagy maximum két dimenzióra korlátozódik. Az ilyeneket leíró modellben a részecskék egy diszkrét láncon vagy rácson mozoghatnak, és közben egymással is kölcsönhatnak.

A DMRG a problémát az ún. mátrixszorzat-állapotos (MPS) reprezentáció használatával kezeli $[9,10]$, ahol minden rácsponthoz egy mátrixot rendelünk, és ezek szorzatával írjuk le a teljes $d$-rácspontos hullámfüggvényt. A DMRG-algoritmus ezeknek a mátrixoknak az elemeit határozza meg iteratív módon, számítási bonyolultságát a mátrixok méretei határozzák meg, szoros kapcsolatban állva a rácspontok közötti korreláció és összefonódottság erősségével $[11,12]$. A reprezentációt még általánosabbá tehetjük, ha mátrixok helyett tenzorokat alkalmazunk, és ezek segítségével építjük fel a hullámfüggvény ún. tenzorhálózat-reprezentációját (TNS) [13-18].

Analóg módon egy molekula minden pályájához rendelhetünk egy mátrixot vagy tenzort, és a teljes hullámfüggvényt kifejthetjük tenzorszorzat-állapotos reprezentációban. A DMRG első kvantumkémiai alkalmazása (QC-DMRG) szintén S. R. White nevéhez köthető [19], amit hamarosan két sikeres implementáció követett $[12,20]$. Köszönhetően az elmúlt két évtized eredményeinek [16,21-27], napjainkra a kvantumkémiai DMRG egy teljesen új megoldást kínál az erősen korrelált molekuláris rendszerek vizsgálatához.

\section{Tenzorhálózat algoritmusok}

Egy $d$ molekulapályával rendelkező molekula hullámfüggvénye másodkvantált formalizmusban felírható

$$
\left|\Psi_{\gamma}\right\rangle=\sum_{\alpha_{1}=1}^{n_{1}} \ldots \sum_{\alpha_{d}=1}^{n_{d}} U\left(\alpha_{1}, \ldots, \alpha_{d}, \gamma\right)\left|\alpha_{1}\right\rangle \otimes \cdots \otimes\left|\alpha_{d}\right\rangle
$$

alakban, ahol betöltésiszám-reprezentációban az $\alpha_{i} a z$ egyrészecskés bázison négyféle értéket $\left(n_{i}=4\right)$ vehet fel: üres, egyszeresen betöltött felfelé vagy lefelé mutató spinnel, illetve kétszeresen betöltött ellentétes spinnel. A $d+1$ indexes $U$ tenzor az ismeretlen hullámfüggvény paramétereket jelöli, melynek elemeit a molekula Schrödinger-egyenletének megoldásából kapjuk. A $\gamma$ a különböző sajátfüggvényeket indexeli. Az $U$ együtthatótenzor grafikus szemléltetése az 1. ábrán látható.

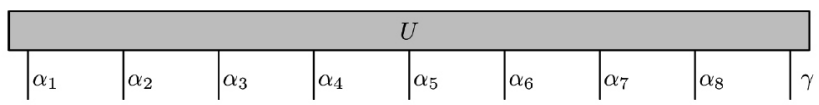

1. Ábra. Együtthatótenzor grafikus ábrázolása 
Könnyen belátható, hogy az $U$ együtthatótenzor mérete a molekulapályák növekvő számával „felrobban”, mivel skálázódása exponenciális. A probléma egzakt megoldása tehát csak kicsi, $d \sim 20$ pályás rendszerekre lehetséges. Ezért olyan közelítő megoldásra van szükség, ami az együtthatótenzor adattömörített változatát biztosítja az által, hogy csak a legfontosabb altérbe eső vetületet tartja meg a hullámfüggvény leírásakor. A továbbiakban csak egy adott sajátfüggvényt vizsgálva (elhagyva a $\gamma$ indexet), egy ilyen reprezentációt biztosít a mátrixszorzat-állapotos megoldás, ahol az $U$ tenzort az egyes molekulapályákhoz rendelt $A$ mátrixok szorzatával írjuk le, azaz

$$
U\left(\alpha_{1}, \ldots, \alpha_{d}\right)=\sum_{m_{1}=1}^{r_{1}} \ldots \sum_{m_{d-1}=1}^{r_{d-1}} A_{1}\left(\alpha_{1}, m_{1}\right) A_{2}\left(m_{1}, \alpha_{2}, m_{2}\right) \cdots A_{d}\left(m_{d-1}, \alpha_{d}\right)
$$

ami grafikusan szemléltetve a 2. ábrán látható.

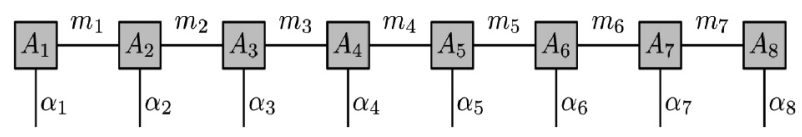

2. Ábra. Együtthatótenzor grafikus ábrázolása MPS reprezentációban

Egy adott $\alpha_{i}$-hez tartozó $A_{l}$ és $A_{d}$ komponenstenzorok a gyakorlatban egyindexes vektorok, $r_{i}$ pedig a mátrixok rangját jelöli, azaz a nem nulla elemek számát az egyes dimenziók mentén. Amennyiben $r_{i} \sim 4^{i}$ egészen a lánc közepéig, úgy az eredeti $d$-indexes együtthatótenzor egzakt reprezentációját kapjuk. A módszer akkor válik hatékonnyá, ha sikerül a mátrixok $m_{i}$ rangját egy véges érték alatt tartani. A DMRG-algoritmus éppen egy olyan optimalizációs eljárás, mely az $A_{i}$ mátrixoknak egy olyan optimális sorozatát adja, amivel az eredeti $d$-indexes együtthatótenzor adattömörített reprezentációját kapjuk egy adott pontosság mellett $[7,9,12]$. Amennyiben mátrixok helyett tenzorokat használunk, úgy még általánosabb hálózatokat kaphatunk [13-18], amint azt a 3. ábrán láthatjuk.
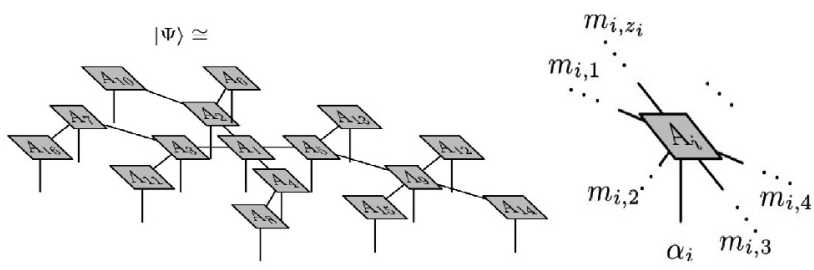

3. Ábra. Hullámfüggvény tenzorhálózat reprezentációja és a komponenstenzor

Ez esetben minden $\alpha_{i}$-hez tartozó komponenstenzornak $z_{i}$ indexe van, azaz $z_{i}$,lába”. A folytonos vonalak összegzéseket jelölnek a hálózatban. A tenzorhálózat algoritmusok esetében a három fő kérdéskör: 1) mi legyen a tenzorhálózat topológiája, 2) hogyan válasszuk meg a komponenstenzorok rangját, 3) milyen egyrészecskés bázis választása az optimális egy adott molekula esetében. Mindezekre választ kaphatunk a kvantuminformációelmélet számos koncepciójának alkalmazásával.

\section{Kvantuminformáció-elmélet}

Amennyiben egy $d$ pályát tartalmazó rendszert részekre osztunk, és csak egy részrendszer tulajdonságait vizsgáljuk, bizonyos esetekben már akkor is információt kaphatunk a teljes rendszerröl. A részrendszerek közötti korrelációk ugyanis a kölcsönhatások révén kialakuló fizikai viselkedésről hordoznak fontos információt. A kvantuminformáció-elmélet (QIT) [28] egyik fö eredménye éppen az ily módon tárolt információ kinyerése. A QIT napjaink egyik legdinamikusabban fejlődő önálló tudományága, így a cikk keretein belül csak egy kiválasztott nagyon szük szegmensével foglalkozunk.

Ha egy $d$ molekulapályát tartalmazó rendszert két részre osztunk oly módon, hogy az egyik részrendszer csak egy, míg a másik $d$-1 molekulapályát tartalmazzon (4.a ábra), akkor képezhetjük az ún. egypályás redukált sürüségmátrixot. Ebből meghatározható az egypályás von Neumann-féle kvantuminformációs entrópia $\left(s_{i}\right)$, melynek értéke 0 és $\ln 4$ között változhat [29,30]. A zérus érték azt jelenti, hogy az adott molekulapálya egyáltalán nem korrelált a többi molekulapályán lévő elektronokkal. A maximális érték pedig azt jelenti, hogy ennek a molekulapályának a legnagyobb a hozzájárulása a teljes korrelációhoz [34] (és az ún. korrelációs energiához). Ez az egypályás ún. összefonódottság teljes mértékben kvantumos eredetü, azaz nem létezik klasszikus analógiája. A fenti eljárást elvégezve két kiválasztott molekulapályára (4.b ábra) az ún. kölcsönös információ, $I_{i j}=$ $s_{i j}-s_{i}-s_{j}$, megadja azt, hogy ez a két pálya egymással mennyire korrelált ( $\mathrm{s}_{\mathrm{ij}}$ a kétpályás entrópia) [31,32]. A kölcsönös információ egyszerre tartalmaz klasszikus és kvantumos korrelációkat [33]. A módszert tovább általánosítva sokféleképpen rendezhetjük a molekulapályákat részrendszerekbe, és vizsgálhatjuk ezek egymással való korrelációit, többek között a többelektronos kémiai kötéseket. Ezen felül gyakran létezik egy optimális felosztás, amikor a részrendszerek szerkezete éppen megegyezik az adott molekula kémiai kötési képével [34]. A részrendszer sürüségmátrix-spektrumának vizsgálata pedig lehetővé teszi a kémiai kötések típusainak meghatározását [35].

(a)

(b)

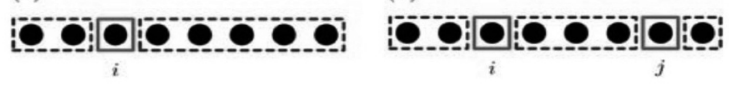

4. Ábra. A hullámfüggvény felosztása részrendszerekre az egypályás entrópia (a) és kétpályás kölcsönös információ (b) számításához

A kvantuminformációs entrópiák egyfajta „fekete-doboz” algoritmust biztosítanak a kémiai kötések kialakulásának és felbomlásának vizsgálatához [36,37], az ún. aktív tér hatékony kiválasztásához [16,29,36,38], az egy- és multireferenciás tulajdonságok vizsgálatához [39]. A fenti eljárást egy kiválasztott példán keresztül mutatjuk be, mely a kémiai kötések szerkezetének megváltozása a $\left[\mathrm{Cu}_{2} \mathrm{O}_{2}\right]^{2+}$ izomerizációja során [36]. A két izomer esetén a 6. és 7. ábrán látható módon igen eltérőek az egypályás entrópiaprofilok (a pályákhoz rendelt körök mérete arányos $s_{i}$ értékével) és a kölcsönös információ profilok (az $I_{i j}$ mátrixelemek erősségét különböző színek jelölik). Elsőként 
megállapítható, hogy a bis( $\mu$-oxo) izomer jóval korreláltabb, ugyanis az egypályás entrópiák általában 20\%-kal nagyobbak, de egyes pályák esetében $(3,14,34)$ ez az arány szinte háromszoros. Az aktív tér pályáinak kiválasztásakor tehát a két izomerre a pályák szerepét más sorrendben célszerü figyelembe venni ahhoz, hogy a legkisebb legyen az információveszteség a számítások során. A peroxo izomer esetén $I_{i j}$-nek nagy értékei vannak a 3-14 és 13-15 pályapárokra, melyek az oxigén-oxigén kötő és lazító pályapárokat írják le. A bis( $\mu$-oxo) izomerre viszont a 3, 13, 14, 34, 35 pályák egyaránt erősen korreláltak a négy réz-oxigén kötésnek megfelelően.

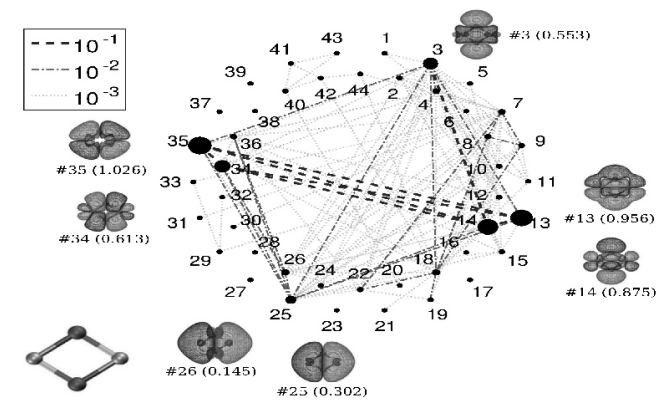

5. Ábra. Az egypályás entrópia, a kétpályás kölcsönös információ és a vonatkozó molekulapályák térbeli szerkezete a bis( $\mu$-oxo) izomerre.

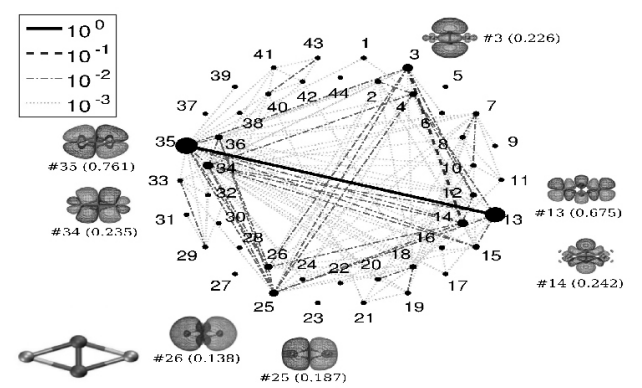

6. Ábra. Az egypályás entrópia, a kétpályás kölcsönös információ és a vonatkozó molekulapályák térbeli szerkezete a $\mu-\eta^{2}: \eta^{2}$ peroxo izomerre.

Mindezek mellett a kvantuminformációs entrópiák segítségével lehet megtervezni egy adott molekulára a tenzorhálózat-algoritmus optimális topológiáját [17,29,36], meghatározni a tenzorkomponensek optimális rangját [12,30] és elvégezni a bázisoptimalizálást [13,40].

\section{4. Új hatékony multireferenciás hibrid algoritmusok}

A különféle módszerek a teljes hullámfüggvény más és más reprezentációit célozzák meg, és mivel mindegyik algoritmus csak egy közelítő megoldást tesz lehetővé, nem meglepő, ha ezek a hullámfüggvény más és más tulajdonságait adják vissza eltérő pontossággal. A tenzorhálózat algoritmusok például a statikus korreláció, míg az egydetermináns alapú, hagyományos CC módszer a dinamikus korreláció hatékony meghatározását biztosítja. Természetesen adódik, hogy a két módszer ötvözésével egy még hatékonyabb eljáráshoz juthatunk: A DMRG alapú külsőleg korrigált coupled cluster (DMRG-TCCSD) módszer $[41,42,43]$ nagy hatékonysággal alkalmazható olyan esetekben, amikor az erösen korrelált rendszerekre kidolgozott CC módszerek már magas számítási igényük miatt nem kivitelezhetők [44].

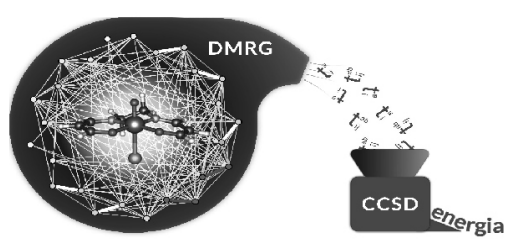

7. Ábra. A DMRG-TCCSD multireferenciás algoritmus sematikus képe.

$\mathrm{Az}$ új algoritmus alapötlete több évtizede ismert, de alkalmazhatóságának feltétele, hogy közel egzaktul meg tudjuk határozni az erősen korrelált molekulapályák által definiált teljes aktív tér ún. CAS hullámfüggvényét, ami csak napjainkra vált lehetővé a DMRG- és TNS-algoritmusoknak köszönhetően. Ehhez elöször az összes molekulapályát tartalmazó Hilbert-teret két részre osztjuk, aktív térre és külső térre (CAS és EXT), és a CAS altéren a DMRG-vel nagy pontossággal meghatározzuk a hullámfüggvényt. A DMRG-ből kapott MPS alakú hullámfüggvényből kinyerjük az egyszeres és kétszeres gerjesztések amplitúdóit, és ezeket tápláljuk be a CC-algoritmusba. A CC-módszer ezáltal nem a referencia Hartree-Fock-determinánsra épül, hanem a DMRG által meghatározott referencia hullámfüggvényre, ami már a legfontosabb (statikus) korrelációkat magában foglalja.

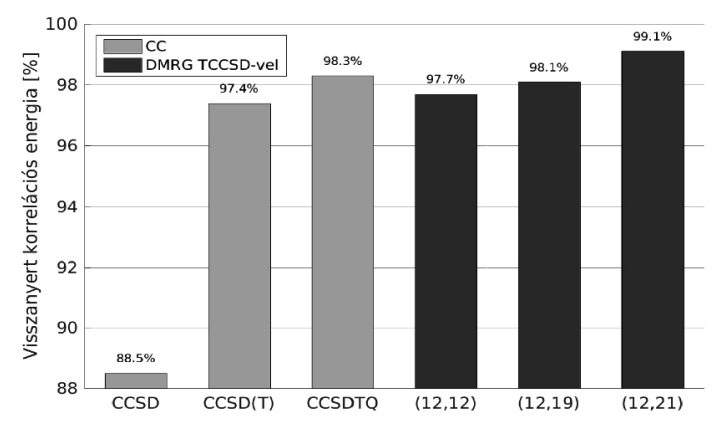

8. Ábra. A DMRG-TCCSD multireferenciás algoritmus hatékonysági tesztje a $\mathrm{Cr}_{2}$ molekulára.

A CAS-EXT optimális felosztást szintén a kvantuminformációs entrópiákkal határozzuk meg: a CAS altérbe azon molekulapályákat vesszük bele, amelyeknek a legnagyobb az egypályás kvantuminformációs entrópiája, vagyis a legösszefontabbak a többi pályával $[29,44]$. A módszer sematikus vázát a 8 . ábra szemlélteti, míg hatékonysági tesztjének eredményét a $\mathrm{Cr}_{2}$ molekulára a 9. ábrán foglaltuk össze. A referenciaként alkalmazott egzakt megoldás egy CAS $(48,42)$ DMRG-számítás [45]. Az ábrán jól látható, hogy a DMRG-TCCSD jóval kisebb CAS terek mellett is igen pontos megoldást biztosít a $\operatorname{DMRG}(48,42)$ referenciához képest, a számítási igény töredéke mellett. A módszer további nagy előnye, hogy megfelelő matematikai precizitással analizálható, és rendelkezik egy kvadratikus hibahatárral [43].

Az Erősen Korrelált Rendszerek „Lendület” kutatócsoport által fejlesztett Budapest-QC-DMRG programcsomag magában foglalja a kvantuminformáció-elméletre épülő optimalizációs eljárásokat, és közel másfél évtizede a világ számos kutatóegyetemén és kutatóintézetében alkalmazzák nagy sikerrel. 


\section{Köszönetnyilvánítás}

A kutatást támogatta az MTA Bolyai János Kutatási Ösztöndíj, az MTA Lendület program, a European Research Area Chemistry program, a Nemzeti Kutatási, Fejlesztési, Innovációs Hivatal (NN110360, K120569), a Nemzeti Kvantumtechnológiai Kiválósági Program (2017-1.2.1- KKP-2017-00001), az OTKA posztoktori támogatás (PD-17-125261), az Emberi Erőforrások Minisztériuma ÚNKP-18-4 kódszámú Új Nemzeti Kiválóság Programja, az MTA Cseh-Magyar kétoldalú kutatási mobilitás program (MTA/16/5).

\section{Hivatkozások}

1. Ciarlet, P.; Lions, J., Handbook of Numerical Analysis: Computational chemistry; Computational Chemistry: Reviews of Current Trends; North-Holland: 2003.

2. Szabó, A.; Ostlund, N. S., Modern Quantum Chemistry; McGraw Hill: New York, 1982.

3. Helgaker, T.; Jorgensen, P.; Olsen, J., Molecular electronic-structure theory; Wiley New York: 2000. https://doi.org/10.1002/9781119019572

4. Rohwedder, T.; Schneider, R. ESAIM: Mathematical Modelling and Numerical Analysis 2013, 47, 1553-1582. https://doi.org/10.1051/m2an/2013075

5. Cramer, C. J.; Wloch, M.; Piecuch, P.; Puzzarini, C.; Gagliardi, L. J. Phys. Chem. A 2006, 110, 991-2004. https://doi.org/10.1021/jp056791e

6. Reiher, M. Faraday Discuss. 2007, 135, 97-124. https://doi.org/10.1039/B605229K

7. White, S. R.; Noack, R. M. Phys. Rev. Lett. 1992, 68, 3487-3490. https://doi.org/10.1103/PhysRevLett.68.3487

8. Schollwöck, U. Rev. Mod. Phys. 2005, 77, 259-315. https://doi.org/10.1103/RevModPhys.77.259

9. Verstraete, F.; Murg, V.; Cirac, J.I. Adv. Phys., 2008, 57, 143-224. https://doi.org/10.1080/14789940801912366

10. Schollwöck, U. Annals of Physics 2011, 326, January 2011 Special Issue, 96-192. https://doi.org/10.1016/j.aop.2010.09.012

11. Vidal, G. ; Latorre, J. I.; Rico, E.; Kitaev, A. Phys. Rev. Lett. 2003, 90, 227902. https://doi.org/10.1103/PhysRevLett.90.227902

12. Legeza, Ö.; Röder, J.; Hess, B. A. Phys. Rev. B 2003, 67, 125114. https://doi.org/10.1103/PhysRevB.67.125114

13. Murg, V.; Verstraete, F.; Legeza, Ö.; Noack, R. M. Phys. Rev. B 2010, 82, 205105. https://doi.org/10.1103/PhysRevB.82.205105

14. Nakatani, N.; Chan, G. K.-L. J of Chem. Phys. 2013, 138, 134113. https://doi.org/10.1063/1.4798639

15. Orús R. Annals of Physics 2014, 349, 117-158. https://doi.org/10.1016/j.aop.2014.06.013

16. Szalay, S.; Pfeffer, M.; Murg, V.; Barcza, G.; Verstraete, F.; Schneider, R.; Legeza, Ö. Int. J. Quant. Chem., 115, 1342-1391. https://doi.org/10.1002/qua.24898

17. Murg, V.; Verstraete, F.; Schneider, R.; Nagy, P. R.; Legeza, Ö. J. Chem. Theory. Comput. 2015, 11, 1027-1036. https://doi.org/10.1021/ct501187j

18. Gunst, K.; Verstraete, F.; Wouters, S.; Legeza, Ö.; Van Neck, D. J. Chem. Theory. Comput. 2018, 14, 2026-2033. https://doi.org/10.1021/acs.jctc. 8 b00098

19. White, S. R.; Martin, R. L. J. of Chem. Phys. 1999, 110, 4127-4130. https://doi.org/10.1063/1.478295

20. Chan, G. K.-L.; Head-Gordon, M. J. Chem. Phys. 2002, 116, 4462-4476. https://doi.org/10.1063/1.1449459

21. Legeza, Ö.; Noack, R.; Sólyom, J.; Tincani, L. In Computational Many-Particle Physics, Fehske, H., Schneider, R., Weiße, A., Eds.; Lecture Notes in Physics, Vol. 739; Springer Berlin Heidelberg: 2008, 653-664.
22. Chan, G. K.-L.; Zgid, D. In, Wheeler, R. A., Ed.; Ann. Rep. Comp. Chem., Vol. 5; Elsevier: 2009, 149-162. https://doi.org/10.1016/S1574-1400(09)00507-6

23. Marti, K. H.; Reiher, M. Zeitschrift für Physikalische Chemie 2010, 224, 583-599. https://doi.org/10.1524/zpch.2010.6125

24. Chan, G. K.-L.; Sharma, S. Annual Review of Physical Chemistry 2011, 62, 465-481. https://doi.org/10.1146/annurev-physchem-032210-103338

25. Kurashige, Y. Mol. Phys. 2014, 112, 1485-1494. https://doi.org/10.1080/00268976.2013.843730

26. Wouters, S.; Van Neck, D. The European Physical Journal D 2014, 68272 https://doi.org/10.1140/epjd/e2014-50500-1

27. Legeza, Ö.; Rohwedder, T.; Schneider, R.; Szalay, S. In Many-Electron Approaches in Physics, Chemistry and Mathematics, Bach, V., Delle Site, L., Eds.; Mathematical Physics Studies; Springer International Publishing: 2014, 53-76. https://doi.org/10.1007/978-3-319-06379-9_3

28. Nielsen, M. A.; Chuang, I. L. Quantum Computation and Quantum Information, 1st ed., Cambridge University Press, 2000.

29. Legeza, Ö.; Sólyom, J. Phys. Rev. B 2003, 68, 195116. https://doi.org/10.1103/PhysRevB.68.195116

30. Legeza, Ö.; Sólyom, J. Phys. Rev. B 2004, 70, 205118. https://doi.org/10.1103/PhysRevB.70.205118

31. Legeza, Ö.; Sólyom, J. Phys. Rev. Lett. 2006, 96, 116401. https://doi.org/10.1103/PhysRevLett.96.116401

32. Rissler, J.; Noack, R. M.; White, S. R. Chemical Physics 2006, 323, 519-531. https://doi.org/10.1016/j.chemphys.2005.10.018

33. Szalay, S. Phys. Rev. A 2015, 92, 042329. https://doi.org/10.1103/PhysRevA.92.042329

34. Szalay, S.; Barcza, G.; Szilvási, T.; Veis, L.; Legeza, Ö. Scientific Reports 2017, 7, 2237. https://doi.org/10.1038/s41598-017-02447-z

35. Szilvási, T.; Barcza, G.; Legeza, Ö. arXiv [cond-mat.str-el] 2015, 1509.04241.

36. Barcza, G.; Legeza, Ö.; Marti, K. H.; Reiher, M. Phys. Rev. A 2011, 83, 012508. https://doi.org/10.1103/PhysRevA.83.012508

37. Boguslawski, K.; Tecmer Paweland Barcza, G.; Legeza, Ö.; Reiher, M. J. Chem. Theory. Comput. 2013, 9, 2959-2973. https://doi.org/10.1021/ct400247p

38. Stein, C. J.; Reiher, M. J. Chem. Theory. Comput. 2016, 12, 1760-1771. https://doi.org/10.1021/acs.jctc.6b00156

39. Boguslawski, K.; Tecmer, P.; Legeza, Ö.; Reiher, M. The J. Phys. Chem. Lett. 2012, 3, 3129-3135. https://doi.org/10.1021/jz301319v

40. Krumnow, C.; Veis, L.; Legeza, Ö.; Eisert, J. Phys. Rev. Lett. 2016, 117, 210402. https://doi.org/10.1103/PhysRevLett.117.210402

41. Veis, L.; Antalík, A.; Brabec, J.; Neese, F.; Legeza, Ö.; Pittner, J. Phys. Chem. Lett. 2016, 7, 4072-4078. https://doi.org/10.1021/acs.jpclett.6b01908

42. Veis, L.; Antalík, A.; Legeza, Ö.; Alavi, A.; Pittner, J. J. Chem. Theory. Comput. 2018, 14, 2439-2445. https://doi.org/10.1021/acs.jctc.8b00022

43. Faulstich, F. M.; Laestadius, A.; Kvaal, S.; Legeza, Ö.; Schneider, R. arXiv [quant-ph] 2018, 1802.05699.

44. Faulstich, F. M.; Máté, M.; Laestadius, A.; Csirik, M. A.; Veis, L.; Antalík, A.; Brabec, J.; Schneider, R.; Pittner, J.; Kvaal, S.; Legeza, Ö. arXiv[quant-ph] 2018, 1809.07732.

45. Olivares-Amaya, R.; Hu, W.; Nakatani, N.; Sharma, S.; Jun, Y.; Chan, G. K.-L. The J. of Chem. Phys. 2015, 142, 034102. https://doi.org/10.1063/1.4905329 


\section{Quantum information encoded in molecules: electronic- structure of transition-metal clusters}

For the approximation of the wave function of the electronic structure of an atomic or molecular system, any method chosen will have to compromise between the demanded accuracy on the one hand, and the high computational complexity of the task on the other. While Density Functional Theory (DFT) and Coupled Cluster (CC) or Quantum Monte Carlo (QMC) methods are in this sense standard methods for the quantitative study of large weakly correlated systems, there has been no method-of-choice solution for finding a sufficiently accurate, data-sparse representation of the exact many-body wave function, if many electrons are strongly correlated. Therefore, computational schemes aiming to describe quasi-degenerate electronic structures of chemical systems are still unreliable, and these multiconfiguration systems form one of the most challenging computational problems in quantum chemistry.

Due to the many-electron interactions present, strongly correlated problems cannot be sufficiently described by small perturbations of a single Slater determinant. For the treatment of other many-particle systems, e.g., spin systems, alternative representations have been proposed, resulting in the development of so-called Matrix Product States (MPS). The MPS method represents the wave function of a system of d components, or "sites" (corresponding, e.g., to molecular orbitals) by forming products of $\mathrm{d}$ matrices, each belonging to one component of the system. The computational complexity of the task is now governed by the size of these matrices, related to the eigenvalue spectrum of the corresponding subsystem density matrices, characterizing in a formal way the so-called entanglement among the different components. MPS is formed by a linear arrangement of the components, while more recently the approach has been generalized to socalled Tensor Network States (TNS), allowing a more flexible connection of the components of the respective system. Identical, but independent approaches were devised in numerical mathematics under the term of tensor product approximation, where low-rank factorization of matrices is generalized to higher order tensors.

In quantum chemistry, the MPS and TNS representation can be used to approximate the full-CI wave function. By this new concept of datasparse representation, an accurate representation of the electronic structure will then be possible in polynomial time, if the exact wave function can be approximated to a sufficient extent by moderately entangled TNS representations.

Quantum information theory has also appeared in quantum chemistry, giving a fresh impetus to the development of methods in electronic structure theory. Recent progresses in optimization tasks connected directly to the manipulation of entanglement, which is in fact the key ingredient of the TNS methods, have already matured to provide a variety of tools to carry out calculations in a black-box manner. Therefore, TNS approaches live their renaissance, in particular, making possible the treatment of problems in quantum chemistry that are intractable by standard techniques as DFT or CC.

The aim of the present paper is to give a pedagogical introduction to the theoretical background of this novel field, and demonstrate the underlying benefits through numerical applications on transition metal clusters. Fingerprint of correlations among the molecular orbitals will be determined by using concepts inherited from quantum information theory, and combination of TNS algorithms with conventional methods will also be presented. 